\title{
If They Come, Where will We Build It? Land-Use Implications of Two Forest Conservation Policies in the Deep Creek Watershed
}

\author{
Markandu Anputhas ${ }^{1}$, Johannus Janmaat ${ }^{1, *}$, Craig Nichol ${ }^{2}$ and Adam Wei ${ }^{2} \mathbb{D}$ \\ 1 Department of Economics, Philosophy and Political Science, I.K. Barber School of Arts and Sciences, \\ The University of British Columbia, Kelowna, BC V1V 1V7, Canada \\ 2 Department of Earth, Environmental and Geographic Sciences, I.K. Barber School of Arts and Sciences, \\ The University of British Columbia, Kelowna, BC V1V 1V7, Canada \\ * Correspondence: john.janmaat@ubc.ca; Tel.: +1-(250)-807-8021
}

Received: 1 June 2019; Accepted: 9 July 2019; Published: 12 July 2019

check for updates

\begin{abstract}
Research Highlights: Forest conservation policies can drive land-use change to other land-use types. In multifunctional landscapes, forest conservation policies will therefore impact on other functions delivered by the landscape. Finding the best pattern of land use requires considering these interactions. Background and Objectives: Population growth continues to drive the development of land for urban purposes. Consequently, there is a loss of other land uses, such as agriculture and forested lands. Efforts to conserve one type of land use will drive more change onto other land uses. Absent effective collaboration among affected communities and relevant institutional agents, unexpected and undesirable land-use change may occur. Materials and Methods: A CLUE-S (Conversion of Land Use and its Effects at Small Scales) model was developed for the Deep Creek watershed, a small sub-basin in the Okanagan Valley of British Columbia, Canada. The valley is experiencing among the most rapid population growth of any region in Canada. Land uses were aggregated into one forested land-use type, one urban land-use type, and three agricultural types. Land-use change was simulated for combinations of two forest conservation policies. Changes are categorized by location, land type, and an existing agricultural land policy. Results: Forest conservation policies drive land conversion onto agricultural land and may increase the loss of low elevation forested land. Model results show where the greatest pressure for removing land from agriculture is likely to occur for each scenario. As an important corridor for species movement, the loss of low elevation forest land may have serious impacts on habitat connectivity. Conclusions: Forest conservation policies that do not account for feedbacks can have unintended consequences, such as increasing conversion pressures on other valued land uses. To avoid surprises, land-use planners and policy makers need to consider these interactions. Models such as CLUE-S can help identify these spatial impacts.
\end{abstract}

Keywords: land-use change; land-use forecasting; agricultural land; forest land; forest conservation; land-use policy; unintended consequences; complex systems

\section{Introduction}

In the 1989 movie "Field of Dreams [1]," the main character hears a mysterious voice say, "If you build it, he will come." This initiates a drama where the main character overcomes various challenges to build a baseball diamond in the middle of a corn field, a diamond which attracts the spirits of many deceased baseball heroes to play their beloved game. Most of the rest of the world is burdened with a different challenge. They are coming, and we do not know where they will live. Hence, our challenge is, "If they come, where will we build it?" 
British Columbia is a largely mountainous province with extensive areas of forest, with the forest industry contributing approximately three percent of provincial GDP [2]. British Columbia's forests also provide many non-timber services that residents' value, including recreational opportunities, wildlife habitat, carbon storage, and landscape aesthetics. These services are generally diminished when forests are harvested, with civil society having a long history of public action in the province to protect forested areas of high value [3,4]. In some cases, these high value forests have strong symbolic appeal, while in other cases the high value forests are valued because they are close to communities where people live. This latter value tends to create pressure for protection of public forested land near urban areas. At the same time, the desire of people to live in the interface regions between urban areas and forests has led to development pressure, evidenced by strong demand for housing in the interface area, on privately held forested land.

Agriculture is also an important industry in British Columbia, contributing approximately twice as much to the provincial GDP as forestry [2]. Less than five percent of the provincial land base is considered arable, with most of that located in valley bottoms along rivers and lakes [5]. These areas are also attractive for human settlement, leading to substantial development pressures on this limited agricultural land base $[5,6]$. There is a long history of public support for protecting agricultural land in the province, witnessed by the passing of the Agricultural Land Commission Act in 1973, and continued public support for the Agricultural Land Reserve (ALR) created by that Act [7]. The ALR is a provincial level land-use zone that includes land of suitable agricultural potential, with uses within that zone in principle limited to activities that do not impact on the ability of the land to be used for agriculture. The ALR is a land reserve, with only about half of the land within the ALR actually being farmed [6]. Land that has been used for development purposes is generally excluded from the ALR, while land that could be brought into production, such as currently forested land with high agricultural potential, is often within the reserve. Exclusions of land currently within the reserve, generally done when such land is developed for urban uses, must in most cases be approved by the Agricultural Land Commission [8].

The authority to direct land-use decisions in British Columbia is fragmented. Jurisdiction over land within the ALR is largely the responsibility of the Agricultural Land Commission, which interacts with the provincial Ministry of Agriculture (formerly BC Ministry of Agriculture and Lands, BCMAL). This ministry is charged with enhancing the economic contribution of agriculture within the province [9]. Jurisdiction over forest and range crown lands lies in large part with the Ministry of Forests, Lands, Natural Resource Operations and Rural Development. This ministry is responsible for the stewardship of provincial Crown land and natural resources [10]. Regulation of the use of private land that is not within the ALR is largely the responsibility of local governments, municipalities, and regional districts that write and enforce zoning bylaws for their area of responsibility [11]. Local governments often prioritize development, which with immigration creates jobs, increases property prices, and the local tax base. Development is often the highest value land use, and as such land owners, who are often well represented in local government, are typically looking for ways to develop their land and realize this highest value.

Policy choices by these different agencies are often made in isolation, and unintended consequences can be the result. In this paper we use a land-use change model to examine how policies aimed at protecting forests can have such unintended consequences on other land uses that society values. In the next section we describe the watershed that is the subject of our land-use change model. We then turn to describing the modeling system we chose to use, the CLUE-S system [12,13], with a brief discussion of its implementation and validation. The results follow. Results are developed for four different land-use policy scenarios. These results are described in relation to the ALR, and to their impact on the location and pattern of land-use change in the watershed. Prior to a short conclusion, results are discussed, examining their implications for policy and extensions of this analysis using alternative land-use change forecasting methods. 


\section{Materials and Methods}

\subsection{Study Site}

The Deep Creek watershed is located in the northern portion of the Okanagan Valley, in the southern part of British Columbia (Figure 1). The watershed covers an area of $230 \mathrm{~km}^{2}$ with the elevation varies between 340 and $1580 \mathrm{~m}$ elevation above sea level [14]. Deep Creek falls under the North Okanagan basin eco-section of Thompson-Okanagan Plateau eco-region [15]. At present, more than half of the watershed area is undeveloped forested land. Montane forest types of Douglas fir and Lodgepole pine are extensively found in the watershed [15].

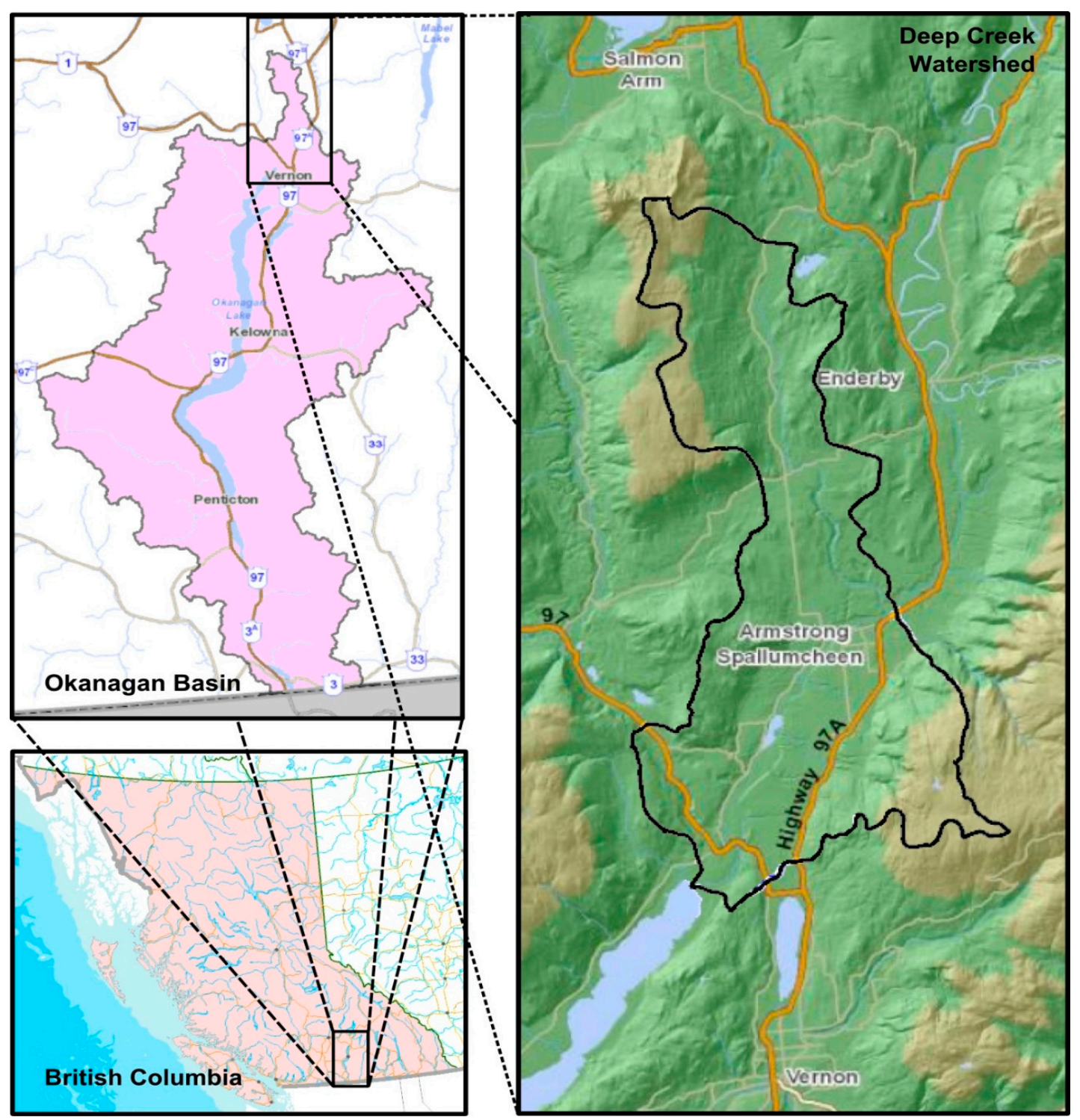

Figure 1. Location of Deep Creek watershed in Okanagan basin of British Columbia, Canada.

The valley has one of the highest rates of population growth in Canada [16,17]. The population trends for the City of Armstrong, Township of Spallumcheen (Armstrong-Spallumcheen local health area), the Regional District of Columbia-Shuswap (RDCS), and the Regional District of North Okanagan (RDNO) show steady positive growth [18]. This growth is not spatially uniform. The population of the City of Armstrong was 4850 in 2011 and the population change from 2006 to 2011 was 13.4\% while the population of the rural Township of Spallumcheen increased from 4960 to 5055 during the same 
period, an increase of $1.9 \%[16,17]$. The dry, relatively warm climate makes the Okanagan Valley an attractive destination for amenity migrants, with those migrants demanding housing and other goods and services $[19,20]$.

The northern portion of the watershed lies within the Regional District of Columbia-Shuswap (RDCS), with the majority contained in the Regional District of North Okanagan (RDNO). Salmon Arm, Armstrong, and Vernon are the major cities that can be easily accessed from within the watershed (Figure 1). Highways 97A and 97B join Vernon and Salmon Arm via Armstrong. This highway travels through the south east portion of the watershed, and then follows a route outside the watershed, along its east and north. Road access in the northern part of the watershed connects to highway 97B. Access to transportation and markets is important for many activities. Farmers need roads to access markets for inputs and to deliver products for sale. Residents use roads to access employment and retail. Much of the Deep Creek watershed is rural residential, with many jobs located in the cities of Vernon and Salmon Arm, both just outside the watershed (Figure 1). Distance to urban centers and access to transportation are important for livelihood activities of the residents in the watershed.

Forestry, agriculture, manufacturing, and tourism are all important economic activities in the watershed. Agriculture is particularly significant in the valley bottom. Livestock farming is the most common category of farming, representing about $21 \%$ of all agricultural operations in the Township of Spallumcheen.

\subsection{The CLUE-S Modeling System}

We used the Conversion of Land Use and its Effects in Smaller scale (CLUE-S) $[12,13,21]$ system, which has proven to be an effective tool for modelling fairly fine scale land-use change. It has been used as land-use change projection tool in African, Asian, American, and European locations [22-27]. This modeling exercise was part of a larger research effort aimed at projecting the impact of climate change on the hydrology of the Deep Creek watershed, similar to [28]. Agriculture is a significant water user within the watershed [14], with predicted changes in agricultural activities therefore being an important part of forecasting impacts on the hydrology of the watershed. Surface and groundwater processes were modeled using MIKE SHE [29], with climate change projections downscaled to a $500 \mathrm{~m} \times 500 \mathrm{~m}$ grid resolution [30]. Given that MIKE SHE is a proprietary product with limited capacity for coupling to a land-use model, it would not be possible to integrate feedbacks between changes in climate and hydrology with land-use decisions. A process-based (e.g., agent-based) land-use change model would therefore miss important drivers, making a pattern-based model both a practical and appropriate approach. Among the set of possible pattern-based models, CLUE-S fit the data availability and needs of the larger project.

A CLUE-S model evolves a gridded map of the study landscape forward, using a probabilistic transition model to forecast land-use changes of individual grid cells. CLUE-S is parameterized using an observation of the landscape at one point in time, with multiple variables measured for each grid cell. Transition probabilities are estimated using a set of logistic regressions, with each land-use type predicted as a function of a set of explanatory variables observed at each cell. The observed relationship between land use and the explanatory variables is assumed to continue forward in time and to be constant across the landscape. CLUE-S does not forecast how much land use will change but rather where changes will take place. Changing trends in aggregate land-use types across the study are taken from other sources. The land-use type of individual grid cells changes as the simulation progresses to match the provided aggregate changes. For this exercise, the growth in urban area is expected to reflect population growth projections [18]. Changes in the relative composition of agricultural activities is taken to be a continuation of past trends [31,32]. "Forest and range" serves as a residual land-use category, adjusted to account for projected changes in the other four land-use categories. See [33] for details of our model construction.

Within CLUE-S, spatial restrictions can be imposed to reduce land-use change or protect a particular land use in an area of the simulated landscape (see for examples $[27,34,35]$ ). We use this 
feature to examine the impacts of two different spatial land-use policies on the evolution of land use in the Deep Creek watershed.

\subsubsection{Calibration}

A $500 \mathrm{~m} \times 500 \mathrm{~m}$ grid cell size was chosen to match available downscaled climate data in use in the Okanagan for multiple parallel climate change related studies. At this resolution, the watershed was covered by just over one thousand cells. A land-use land cover map was obtained from the BC Ministry of Agriculture [36,37]. The land-use map was based on a subdivision of agricultural parcels by land use determined by satellite photos and verified by roadside observations [38-40]. The polygon data was converted to a raster with each pixel representing a $100 \mathrm{~m} \times 100 \mathrm{~m}$ land unit. The dominant land-use type was assigned to each pixel. In almost $82 \%$ of pixels the dominant land use occupied a majority of the land unit, while for less than $5 \%$ of pixels the dominant land use accounted for less than one third of the land unit. There were 42 major land-use types across the watershed raster map. These land-use types were aggregated into three broad categories, undeveloped, agricultural, and urbanized, with the agricultural category further subdivided into cultivation land, livestock farm, and pasture and forage land. The undeveloped land was primarily forest. Undisturbed Okanagan forest supports some grasses, with greater grass development in recently cut areas, leading to crown grazing leases that use of a portion of this area as cattle range. We therefore label this category "forest and range". The urbanized category was labeled "residential and built". In contrast to undeveloped range, "pasture and forage" lands have been actively planted and are used for grazing or the production of forage. "Cultivation lands" are used for annual and perennial crops that are not primarily for animal consumption. "Livestock farm" are lands that are primarily for housing or otherwise containing higher densities of livestock. Each $500 \mathrm{~m} \times 500 \mathrm{~m}$ grid cell was assigned the dominant land use from the 25 pixels it contained. The resulting land-use map is shown in Figure 2.

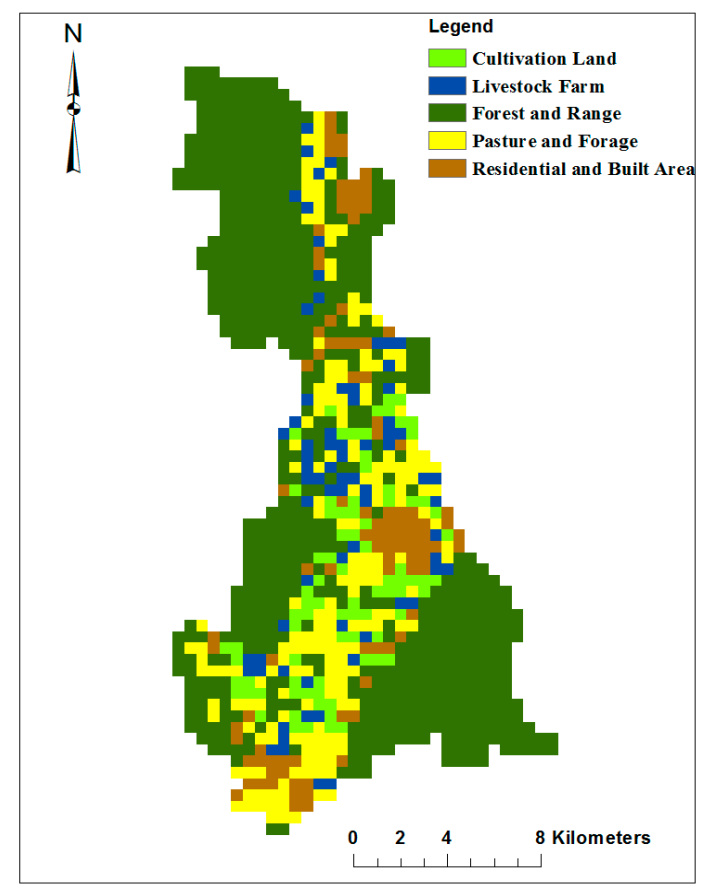

Figure 2. Major land uses and their spatial distribution in the study area for year 2008.

A further set of socioeconomic, biophysical, and spatial variables potentially affecting land use was identified and scaled to match the grid size. Data sources included senior government (e.g., BCMAL), local governments (e.g., the Okanagan Basin Water Board, OBWB), and the Internet. For elevation and slope, a digital contour map [41] was rasterized at a $25 \mathrm{~m} \times 25 \mathrm{~m}$ scale with elevation and slope 
calculated for each of these smaller raster pixels. The 400 pixels in a grid cell were then averaged. The same approach was used for soil characteristics from Soil Landscapes of Canada [42]. The slope orientation for each pixel was determined as one of the four compass directions, with the aspect of the cell being the dominant orientation for the contained pixels. Distance measures were calculated from the centroid of each $25 \mathrm{~m} \times 25 \mathrm{~m}$ pixel to the feature of interest (road, etc). The distance assigned to the cell was the average of the pixel distances. In this way, a $500 \mathrm{~m} \times 500 \mathrm{~m}$ grid cell with two roads equidistant from the centroid would have a lower distance measure-more of the land is close to a road - than a similar cell with only one road. Similarly, a road that curves around a cell will generate a smaller distance measure than one that follows one edge, even as the distance to the cell centroid would be the same. The number of households within each grid cell was calculated using latitude and longitude of each household that was identified by a reverse postal code lookup [43]. Finally, spatial association is a measure of the frequency of adjacent cells having the same land-use type. This is a measure proposed by the authors and described more fully elsewhere [33].

The biophysical, socioeconomic, and spatial variables were used as predictors in a set of logistic regressions, the results of which are a central input to the CLUE-S system. A logistic regression has the form

$$
\operatorname{Pr}\left(Y_{i}=1\right)=\frac{1}{1+\exp \left[-\left(\beta_{0}+\beta_{1} x_{1 i}+\ldots+\beta_{k} x_{k i}\right)\right]}
$$

where $Y_{i}=1$ for those cells of the land-use type being considered and $Y_{i}=0$ for all other land-use types. The variables $x_{1 i} \ldots x_{k i}$ are the predictors, and the parameters $\beta_{0} \ldots \beta_{k}$ are to be estimated. The estimated regression equations are then used to generate a probability that each cell will be each land-use type. If an increase in a particular land use is predicted, then, all else equal, that land use will occur in those cells that have the highest probability of being that land use. CLUE-S uses the regression results in this way to predict where land-use change is likely to occur on the landscape. Their impact on the transition probabilities used within the model is shown in Table 1. Values for the parameters and a more detailed interpretation can be found in [33]. A central assumption maintained when using the CLUE-S system is that the parameters and predictors are constant for the duration of the simulation run.

Table 1. Direction of transition probabilities for exogenous driving variables included in the logistic regressions used to calibrate the CLUE-S model.

\begin{tabular}{|c|c|c|c|c|c|}
\hline \multirow[b]{2}{*}{ Variables } & \multicolumn{5}{|c|}{ Transition Probability Impact } \\
\hline & Cultivation Area & Farm Area & Forest and Range & Pasture and Forage & $\begin{array}{c}\text { Residential } \\
\text { and Built Area }\end{array}$ \\
\hline Constant & - & - & - & - & + \\
\hline \multicolumn{6}{|l|}{ Socioeconomic } \\
\hline Dist. to highway & NS & NS & + & NS & - \\
\hline Dist. to urban ctr. & + & NS & NS & NS & - \\
\hline Dist. to paved road & - & - & + & NS & NS \\
\hline Population density & - & NS & - & - & + \\
\hline \multicolumn{6}{|l|}{ Biophysical } \\
\hline Slope & - & - & + & - & NS \\
\hline $\begin{array}{l}\text { Depth to } \\
\text { groundwater }\end{array}$ & - & - & + & - & - \\
\hline North aspect & NS & NS & NS & + & NS \\
\hline South aspect & + & NS & NS & NS & NS \\
\hline East aspect & NS & + & NS & NS & NS \\
\hline $\begin{array}{c}\text { Percentage sand } \\
\text { Spatial }\end{array}$ & NS & + & NS & NS & + \\
\hline $\begin{array}{l}\text { Dist. to } \\
\text { lake/reservoir }\end{array}$ & NS & NS & + & NS & - \\
\hline Dist. to River & + & NS & - & NS & NS \\
\hline Spatial assoc. & + & + & Excld & + & NS \\
\hline
\end{tabular}

Elevation, soil depth, distance major city (Vernon or Salmon Arm), and \% of silt also considered in the model but dropped due to insignificance or misleading. Transition probability impact is assumed at the start of the simulation. "+" denotes increase in transition probability and " - " denotes decrease in transition probability; NS-not important/significant; Excld (Excluded). 
Land-use transitions within the model are also modified by transition elasticities and iteration probabilities (see $[13,21]$ ). These capture directionality that may not be reflected in the prediction probabilities. In particular, land that has been converted from any use to residential and built is not expected to be converted to any other use, regardless of the predicted probabilities. Likewise, the probability that any land-use type will be converted back to forest and range is expected to be low.

\subsubsection{Validation}

Unfortunately, we did not have a land-use classification map for two dates, and therefore could not calibrate the model at one date and compare the forecast land-use pattern with the observed land use at the other date. To generate a land-use map, we performed a discriminant function-based land-use classification, an approach common in remote sensing disciplines [44-46]. LANDSAT reflectance bands for 2010 [47] were used to calibrate discriminant functions for each land-use type from a known land-use map for 2008. This discriminant function was then used to classify land types using LANDSAT images collected in 1993. We then ran our simulation backwards from 2007 to 1993 and compared the model reverse forecast (simulated map) with the generated land-use map (classified map using satellite data).

The simulated and classified maps of 1993 were examined for prediction accuracy. Both single and multiresolution techniques were used $[48,49]$. The multiresolution evaluation has been suggested in the literature but has seldom been used [50]. The key distinction between single resolution and multiresolution approaches is that the latter is forgiving of near misses. Using the single resolution cell-by-cell measure, our forecast model had an error of slightly over $20 \%$. When we considered a multiresolution approach, we found that the error decreased rapidly as the resolution was increased. Our results suggest that much of the error in our forecast was due to 'near misses', where the model predicted well the general trend of land-use change but did not precisely predict the changes at the level of each cell.

\subsection{Scenarios}

Two policies restricting the conversion of undeveloped land to other uses were considered, inspired by local Official Community Plans (OCPs), the policy direction of the Regional District of Columbia Shuswap (RDCS) [51], and provincial and federal policy directions [51-53]. The "forest conservation" policy halts the conversion of forested land throughout the watershed to other uses after 2030. The "area restriction" policy halts conversion of forest land in the northern part of the watershed, that part in the RDCS, for the duration of the simulation. Intersected, this gives four policy scenarios (Table 2).

Table 2. Policy scenarios investigated.

\begin{tabular}{|c|c|c|c|}
\hline \multirow{4}{*}{ Area Restriction } & \multicolumn{3}{|c|}{ Forest and Range Land } \\
\hline & & Free to Chang & Conserved \\
\hline & Not imposed & Business As Usual (BAU) & $\begin{array}{l}\text { Conservation without } \\
\text { area restriction }(\mathrm{C})\end{array}$ \\
\hline & Imposed & $\begin{array}{l}\text { Area restriction without } \\
\text { Conservation (AR) }\end{array}$ & $\begin{array}{l}\text { Conservation with area } \\
\text { restriction }(\mathrm{CAR})\end{array}$ \\
\hline
\end{tabular}

No land-use policy is ever written in stone. For the purpose of our simulation, we treated the forest conservation and area restriction policies as strictly followed, while treating the agricultural land reserve as if it was not enforced at all. Treating the ALR as strictly enforced together with the policy scenarios set out above would have forced all model land-use change to occur in the small number of cells not covered by these restrictions. In reality, neither the ALR nor the examined policy scenarios will be followed precisely. For our purposes, we ran the scenarios as if there was no ALR, to see where land-use change would occur if this were the case. Our results can therefore be taken as indicating where the most pressure will be to exclude land from the ALR. 


\section{Results}

\subsection{Simulation Results}

Figure 3 shows the predicted land-use patterns for the watershed in 2050 for each of the four scenarios. Aggregate changes are set out in Table 3. In the table, each row represents a land use, and the total of the row is the number of grid cells of that land-use type in 2010. The sum of each column is the total number of cells of that land-use type in 2050. Each table entry contains the number of grid cells that were of the row type in 2010 and of the column type in 2050. Numbers along the diagonal count the grid cells that had the same land use in 2010 and 2050. The off-diagonal numbers show the loss (row land use)/gain (column land use) from land-use change. The loss of presently farmed agricultural land (the sum of cultivation land, livestock farm, and pasture and forage land-use types) varies between $1 \%$ and $12 \%$ across the scenarios. Overall, $85 \%$ to $90 \%$ of the watershed will remain the same in 2050 irrespective of the scenarios (Table 1).

Table 3. Aggregate land-use changes by land-use type for all four scenarios, together with changes specific to land within the agricultural land reserve. The values in parentheses count cells that are in the ALR.

\begin{tabular}{|c|c|c|c|c|c|}
\hline & & & 2050 & & \\
\hline & Land-Use Category & $\begin{array}{l}\text { Agricultural } \\
\text { Land }\end{array}$ & $\begin{array}{c}\text { Forest and } \\
\text { Range }\end{array}$ & $\begin{array}{c}\text { Residential } \\
\text { and Built Area }\end{array}$ & $\begin{array}{l}\text { Remain as } \\
\text { Original in \% }\end{array}$ \\
\hline \multirow{5}{*}{ 웅 } & & \multicolumn{4}{|c|}{ Business as Usual-BAU } \\
\hline & Agricultural land & $343(312)^{1}$ & $0(0)$ & $7(7)$ & $98(98)$ \\
\hline & Forest and Range & $98(69)$ & $510(28)$ & $51(19)$ & $77(24)$ \\
\hline & Residential and Built area & $0(0)$ & $0(0)$ & $103(61)$ & $100(100)$ \\
\hline & In 2050 & $441(381)$ & $510(28)$ & $161(87)$ & $86(81)$ \\
\hline \multirow{5}{*}{ 웅 } & & \multicolumn{4}{|c|}{ Conservation without Area Restriction-C } \\
\hline & Agricultural land & $308(288)$ & $8(6)$ & $34(25)$ & $88(90)$ \\
\hline & Forest and Range & $50(43)$ & $585(61)$ & $24(12)$ & $89(53)$ \\
\hline & Residential and Built area & $0(0)$ & $0(0)$ & $103(61)$ & $100(100)$ \\
\hline & In 2050 & $358(331)$ & $593(67)$ & $161(98)$ & $90(83)$ \\
\hline \multirow{5}{*}{ 웅 } & & \multicolumn{4}{|c|}{ Area restriction without Conservation-AR } \\
\hline & Agricultural land & $345(314)$ & $0(0)$ & $5(5)$ & $99(98)$ \\
\hline & Forest and Range & $92(62)$ & $510(26)$ & $53(28)$ & $77(22)$ \\
\hline & Residential and Built area & $0(0)$ & $0(0)$ & $103(61)$ & $100(100)$ \\
\hline & In 2050 & $441(376)$ & $510(26)$ & $161(94)$ & $86(81)$ \\
\hline \multirow{5}{*}{ 웅 } & & \multicolumn{4}{|c|}{ Conservation with Area Restriction-CAR } \\
\hline & Agricultural land & $312(289)$ & $4(4)$ & $34(26)$ & $89(91)$ \\
\hline & Forest and Range & $46(40)$ & $589(59)$ & $24(17)$ & $89(51)$ \\
\hline & Residential and Built area & $0(0)$ & $0(0)$ & $103(61)$ & $100(100)$ \\
\hline & In 2050 & $358(329)$ & $593(63)$ & $161(104)$ & $90(82)$ \\
\hline
\end{tabular}




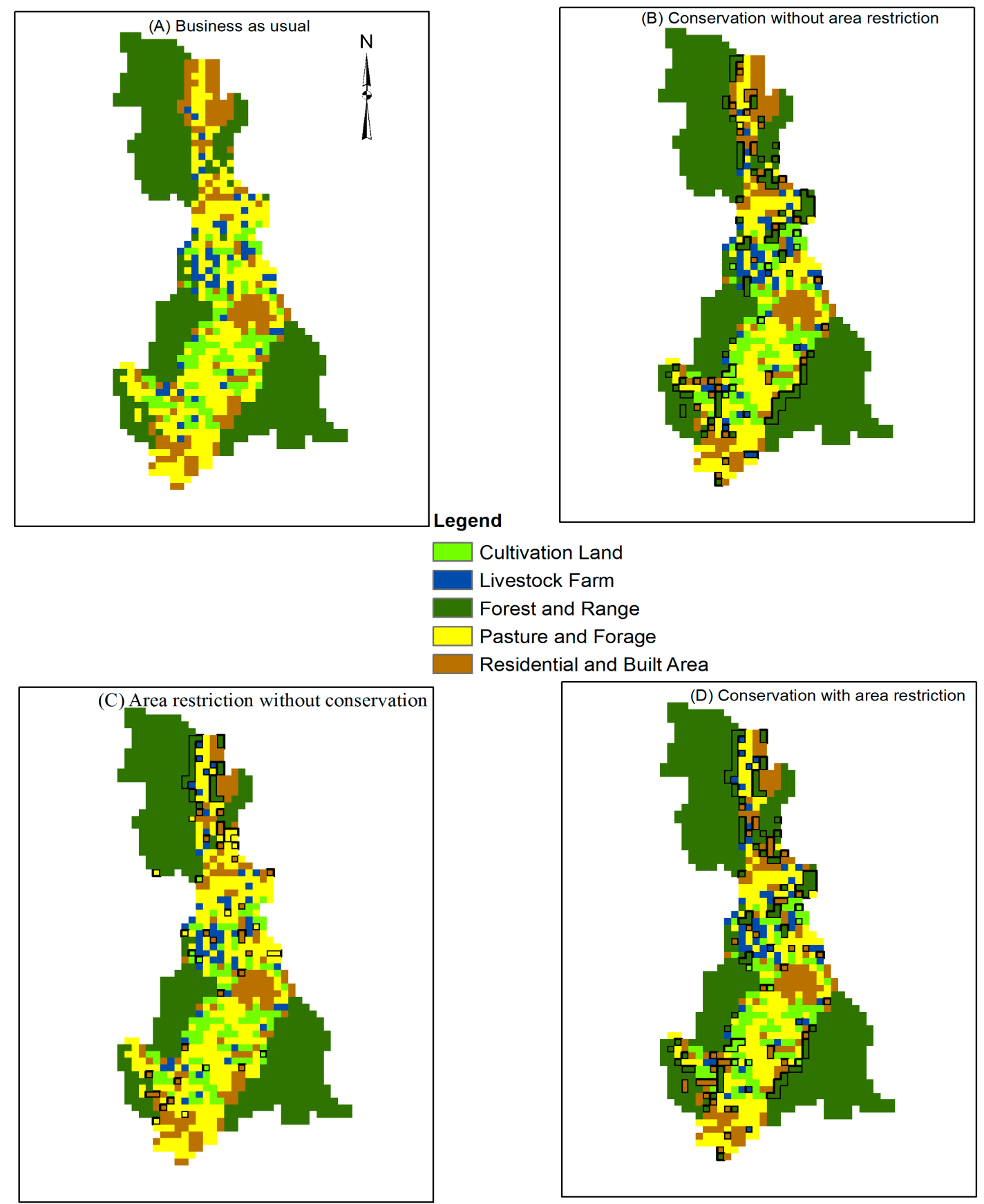

Figure 3. Projected land-use changes at 2050 under four varying scenarios. (A) Business as Usual (BAU) scenario, with no new forest conservation policies; (B) Conservation without Area Restriction (C) policy scenario, where conversion of forest land is halted from 2030 onwards; (C) Area Restriction without Conservation (AR) policy scenario, where forest development in that part of the watershed inside the Regional District of Columbia Shuswap is halted throughout; (D) Conservation and Area Restriction (CAR) policy scenario where both policies are in place. Grids with difference in land use from BAU are indicated by surrounding borders for other scenarios.

\subsubsection{Business as Usual (BAU)}

Livestock farming is expected to decline and cease their operation in the mountainous region and the valley bottom whereas it is expected to continue as at present in the central area (closer to Armstrong) (Figure 3A). The expansion of residential and built area is most prominent in the north-east and in the valley bottom of the watershed (Figure 3A) areas on the urban fringe of the cities of Salmon 
Arm and Vernon. Proximity to these cities and to road networks (paved surface road and highways) linking grid cells to these cities increases the likelihood of conversion.

\subsubsection{Conservation without Area Restriction (C)}

Halting conservation of forested land after 2030 results in 83 fewer cells being converted from forest to other uses. The result is that 83 additional cells that were initially for agricultural use were converted to residential and built uses at the end of the simulation. This development occurs largely on cells that are near those in the BAU scenario, substituting development of agricultural land near the forest and range land that is forecast to be built on when there are no restrictions (Figure 3B). Proximity to these urban centers and to the transportation network continues to be the important drivers, subject to the imposed restriction. Further, the initial conversions prior to 2030 make it more likely that agricultural parcels near the forest land that was converted will be converted.

\subsubsection{Area Restriction without Conservation (AR)}

This restriction prevents conversion of forest and range land to other uses in the northern part of the watershed in the RDCS. The decline of forest area therefore shifts to the south-west part of watershed (Figure 3C). This puts increased pressure on forest land, particularly low elevation forest land in the center of the watershed. This land is particularly suitable for agricultural uses and is in effect substituted for agricultural land that is developed for residential and built area in the northern part of the watershed. The restriction drives residential and built area conversion from the forest and range land to agricultural land in the area where the restriction is in place. This means that the growth in cultivation and pasture and forage land must occur elsewhere in the watershed. The importance of the proximity to urban areas and the proximity to transportation are what keeps the residential and built area development from moving too far. Given the scarcity of suitable land, residential and built area conversion in the north part of the watershed does move south, closer to the border between CSRD and RDNO, compared to the BAU. These results agree with the OCP of RDNO, in which these areas are medium holding lands reserved for development, including the residential and built area (RDNO, 2012).

\subsubsection{Conservation with Area Restriction-(CAR)}

Combining the two restrictions means that forest and range land in the northern part of the watershed cannot be developed for the duration of the simulation, and conversion of the remaining forest and range land does not occur after 2030. Consequently, the 89 grid cells that are not converted from forest and range to other uses must all be accommodated in the agricultural land portions of the watershed and primarily in the southern part of the watershed (Figure 3D). Proximity to urban areas and distance to transportation continue to be the important drivers for conversion to residential and built area. This means that conversion to agricultural uses or conversions between agricultural uses work together to expand agricultural area significantly in the central part of the watershed. This expansion is taking place in that part of the watershed farthest from the major urban centers and somewhat distant from the highway connecting these centers.

\subsection{Agricultural Land Reserve, Agricultural and Forest Land Impacts}

Figure 4 summarizes the impacts of the four scenarios on land within the ALR, land below $550 \mathrm{~m}$ elevation, and land in the north, central, and south portions of the watershed. For mapping, we marked those cells where at least $50 \%$ of the cell area is within the ALR as ALR. The last four delineations are for convenience and illustrative purposes. The elevation cutoff is 'just right,' in a Goldilocks sense, for including forest patches that are embedded in agricultural land and excluding most forest that is at the interface between agricultural and forested land. The north, center, and south division is a convenient partition into thirds. For interpreting the results in Figure 4, it is important to bear in mind that our simulation does not forecast the amount of land-use change that will occur but 
where a previously decided total amount of land-use change will be located within the confines of aggregate restrictions such as those imposed for the tested scenarios. Thus, the total amount of land used for agricultural purposes will increase at the expense of some forested land within the limits of the restrictions imposed. The total amount of residential and built area in 2050 will be the same in all scenarios, with the difference being where it is located.
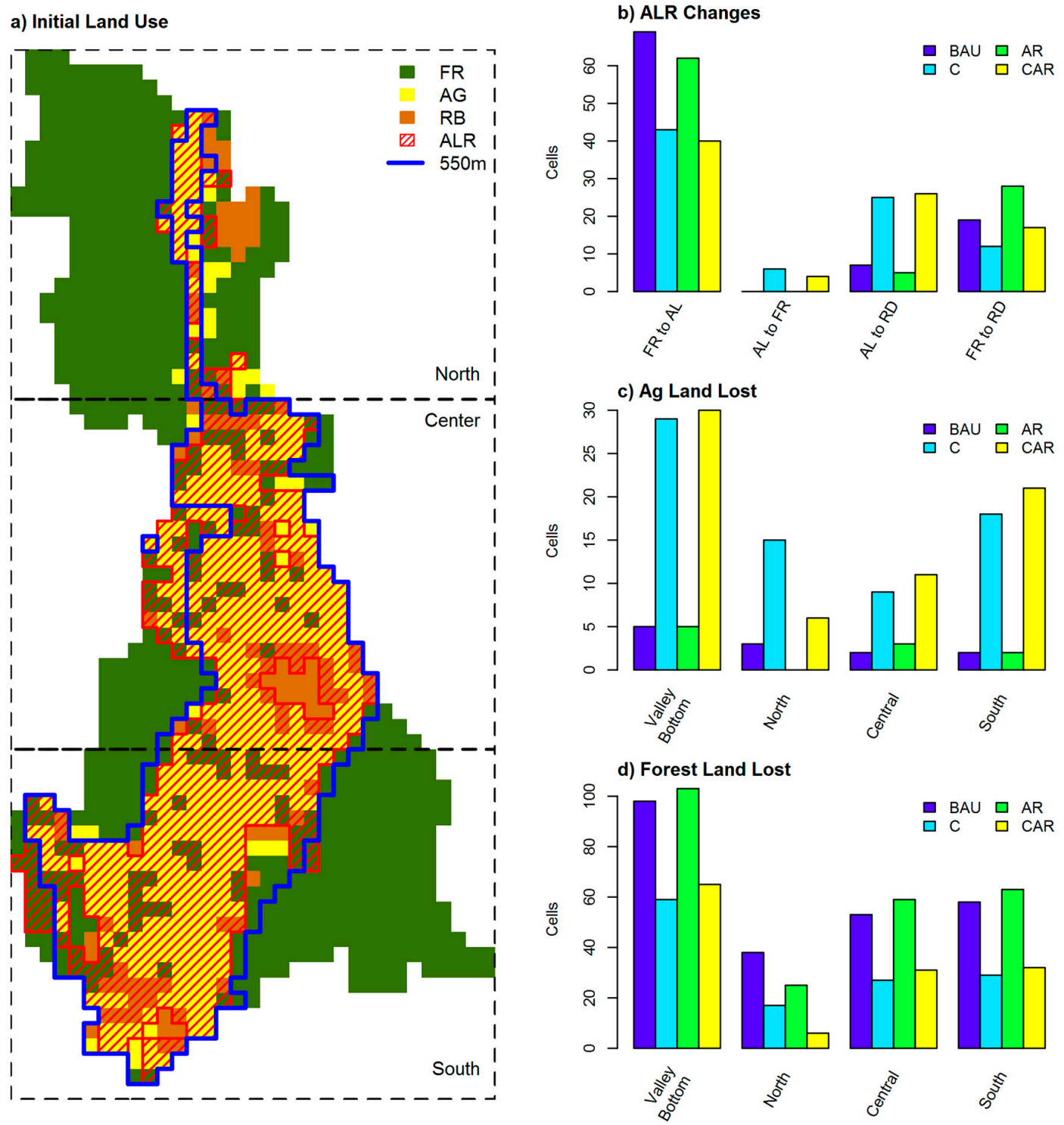

Figure 4. Summary of land-use changes. Land-use types are forest and range (FR), agricultural (AR) and residential and built (RB). Policy scenarios are business as usual (BAU), forest conservation after 2030 (C), restriction of forest conversion in the RDCS part of the watershed (AR), and both forest conservation policies together (CAR). ALR refers the Agricultural Land Reserve, and land below $550 \mathrm{~m}$ is considered valley bottom. (a) Map of initial land uses, with areas of interest identified; (b) changes to land within the ALR; (c) location of loss of agricultural land; (d) location of loss of forest and range land.

Restrictions on forest land-use change have impacts on the ALR. Land within the ALR does not need to be used for agricultural purposes but have agricultural potential. Forest and range cells within the ALR in Figure 4a identify such lands. Conversion of land from forest and range within the ALR to agriculture within the ALR has no impact on total land within the ALR. Relative to no policy (BAU), the area restriction has little aggregate impact on land in the ALR. The total amount of forest and range inside the ALR that is converted to other uses is slightly lower than in the BAU case (Figure 4b). 
However, the portion of forested land within the ALR converted to residential or built is higher. Forest conservation $(\mathrm{C})$ has the desired effect, reducing the amount of forested land converted to other uses. However, this increases by approximately four times the amount of agricultural land inside the ALR that is converted to residential and built. Restricting conversion of forested land in one part of the watershed (AR) shifts the conversion to forested land in the watershed not subject to the restriction. Restricting conversion of all forested land (C) shifts the conversion to agricultural lands not subject to the restriction, much of which is in the ALR. Since the ALR was not enforced in the model, the actual land conversion to residential and built will be lower inside the ALR if the ALR is enforced. In that case, all land conversion after 2030 would occur in the remainder of the 31 cells that at the start of the simulation were not the forest and range land-use type and not already built. Prior to 2030, if the ALR is enforced, much more development will occur on forest and range land than without an enforced ALR.

The policy scenarios that involve protecting forest and range after 2030 drive a large increase in the conversion of agricultural land, agricultural land that may or may not be in the ALR (Figure 4c). Most of this occurs in the valley bottom and is conversion from agricultural land to residential and built. Since residential and built is a collector state, all of the conversion to residential and built is 'lost' agricultural land as in the model it will never be converted back to agriculture. In the BAU scenario there are two more agricultural cells lost than in scenario AR. Two agricultural cells at higher elevation would have been converted before the end of the simulation if forest and range conversion in the RDCS was not restricted. The interaction between RDCS forest protection and overall forest protection after 2030 (CAR) drives development further south and has less impact on agricultural land in the north. This is a consequence of the spatial association included in our model. We have documented strong evidence that land-use conversion tends to drive similar land-use conversion nearby in this watershed [33]. When forest conversion is limited after 2030, there is substantial loss of agricultural land in the north. When the development of forest land in the north is restricted, it makes the development of agricultural land less attractive. When AR is in place on its own, no agricultural land in the north is lost. When C and AR are combined, less than half as much agricultural land is lost than when $C$ is the only policy. In effect, the AR policy drives development away from agricultural land in the north by providing less residential and developed cells near agricultural cells to increase the conversion probability.

Forestry policies also impact forest and range in the valley bottom and affect where lower watershed changes occur. Figure $4 \mathrm{~d}$ reports the net amount of forest and range land lost. As can be noted in Figure 4b, agricultural land is sometimes converted to forest and range land in the model. However, this reverse conversion is rare in the Okanagan, where climate change is making the land suitable for a wider variety of crops and population growth and taste trends are together driving an increase in the demand for locally grown food. One interesting result is that stopping the development of forest and range land in the RDCS (AR) increases the loss of forest in the valley bottom. While the effect in the model is small, one cell, it is noteworthy because there is limited forest and range land in the valley bottom and therefore represents habitat that is particularly important for species that prefer low elevations and for providing corridors for such organisms to travel between watersheds. It is also noteworthy that the AR policy increases forest conversion in the central and southern parts of the watershed. Implementing the AR policy in the RDCS achieves the RDCS objective of protecting forested land within their jurisdiction. However, from a watershed perspective, it does not protect forest and range cells. Rather, it drives the conversion to that portion of the watershed not within the jurisdiction of the RDCS. Protecting forest and range cells throughout the watershed after 2030 reduces overall conversion out of this land-use type but does not undo the transfer of forest conversion out of the RDCS area and into other parts of the watershed.

\section{Discussion}

Landscapes are multifunctional [54]. They provide a variety of services, ranging from the production of food and fibre through to recreational opportunities and habitat for non-humans. 
Managing a multifunctional landscape is challenging, both on account of the complexities inherent in the interconnections among processes operating on the landscape and on account of the human agents on the landscape who have a diversity of sometimes conflicting interests in how the landscape evolves [55-57]. Our modeling exercise highlights the potential for unintended consequences when chosen policies do not account for the feedbacks whereby an action in one part of the landscape feeds into decisions elsewhere on the landscape. That these challenges exist is well known [57-60], with [61] an example where nature protection in one location has effects at other locations. Successfully integrating them into land-use planning and management has been the challenge $[62,63]$.

The empirical analysis that calibrated our model [33] demonstrated that for this watershed, distance from a paved road and major urban centers are important predictors of land-use change, together with an important tendency for conversion to favor land uses that are already present in neighboring cells (spatial association). These drivers interact with the simple policies halting the conversion of forest and range land in a portion of the watershed and/or after a particular date to generate the predicted pattern of land use. These knock on effects lead to potentially undesirable impacts on socially important landscape functions, food production, and low elevation natural habitat. Ideally, policy makers would take these interconnections into account and promote the pattern of land use that best balances the societal value of the landscape functions at a watershed scale. The governance system makes this challenging.

The governance system is that collection of formal and informal institutions and processes that together determine how resources will be used and by whom. Governance is fragmented when the authority is divided between different institutions, which may be multiple local governments within a watershed and/or multiple senior government agencies with different and possibly conflicting mandates having authority within the same watershed. The fragmentation of water governance in Canada has been pointed to as a cause of poor water management outcomes [64]. Globally, this fragmentation is the dominant pattern when many environmental and resource issues are considered [65]. Fragmentation makes it challenging for decision makers to coordinate their actions to achieve land-use patterns that best serve society's interests. Our results highlight the importance of coordination. If the two regional governments that span the watershed do not coordinate their policies, then if the RDCS protects forests within its jurisdiction, this will increase the loss of forest and range land, and agricultural land, in the area governed by the RDNO. Likewise, if large scale forest protection policies come into place, likely driven in BC by the Ministry of Forests, Lands, Natural Resource Operations and Rural Development, our results demonstrate that this will put extra development pressure on agricultural land, the protection of which is the responsibility of the Agricultural Land Commission. The challenge posed by governance fragmentation for effective climate change adaptation by agriculture has also been recognized [66].

Our model results also show that one policy, halting the conversion of forested land in that part of the watershed within the RDCS, may actually increase the conversion of low elevation forest elsewhere in the watershed. The Okanagan Valley serves as the only low-elevation, arid corridor connecting the arid interior of Washington State to the south and the arid south-central interior of British Columbia $[67,68]$. Thus, if care is not taken in choosing forest protection policies, protecting specific parts of the forest in the watershed may reduce the resilience of the ecological systems in the watershed and even beyond its boundaries. The consultations needed to ensure that the best combination of landscape functions is sustained need to go well beyond the conventionally considered interested parties to ensure that all landscape functions are considered.

A maintained assumption in this analysis is that the processes of land-use change, as embodied in the logistic regression parameters and the underlying biophysical and socioeconomic data, remain the same over the duration of the simulation. Given that the climate change projections to which these land-use patterns were to be matched are based on emissions scenarios not coupled to the climate change projections, the CLUE-S system is the appropriate tool for this analysis. However, the analysis 
of policy scenarios that cannot be described with area restrictions will require a process-based model that incorporates the response of decision makers on the land to the policies.

Emphasizing higher density and directing new development towards areas that already have some development (infill development) would be policies that would reduce the conversion of agricultural and forest lands to residential and build areas, reducing the magnitude of the changes forecast by our model. Land-use conversion restrictions may also drive development out of the watershed to areas where those restrictions are not in place. The province recently introduced a tax on residential units that are vacant most of the year, as a way of making more rental housing available. This tax was only applied in the larger and more expensive property markets. There is anecdotal evidence that this is driving development into nearby communities where the tax is not in place and therefore the cost of owing residential property is lower. This tax may result in increased the pressure for development in the study watershed. Payments for ecosystem services may work in the opposite direction, providing a financial reward for protecting the land in a more natural state. One important extension of this analysis would be an examination of how incentive-based policies that operate through the land market can redirect development and/or change its form.

The price for which land trades in a land market is itself a consequence of the uses to which that land can be put. The value of agricultural land is a derived value, based on the value of the products that can be grown on the land. The province brought into being the ALR at a time when the profit land owners could earn farming their land was far less than the profit they could earn by developing their land. Climate change promises to increase the range of crops that can be grown in the Okanagan, while potentially leading to declines in other areas. In the future, the price of what can be grown from the land may serve to reduce the pressure for conversion of agricultural land to residential and built, while increasing the pressure to convert forested land to agriculture. Extending this work by using a process-based model can help illustrate how changes in agricultural commodity prices may affect land uses and water demand.

The importance of markets and incentive-based policies is a consequence of the fact that almost all of the agricultural and build land area in the watershed is private property, as is some of the lower elevation forested land. Halting land conversion on public lands is relatively easy, when contrasted with halting land conversion on private lands. Private land owners typically have the right to do anything they would like to do with their land, provided there are no clear and traceable adverse impacts on other land owners or the public at large. Policies that directly mandate the use that private owners can make of their land are strongly resisted, leaving such command and control policies to situations where the adverse impacts of particular uses are obvious and strongly detrimental. Such was the case in the implementation of the ALR to restrict rapid conversion of the scarce provincial agricultural land base. Most policies must therefore rely on persuasion, either moral suasion or through incentive-based policies, such as payments for ecosystem services [69-73]. The policy must make that land use which is best for society be that one which is preferred by the private land owner [74]. Our analysis provides an 'as if' analysis, as if land-use restrictions could be effectively implemented. Those proposed are reasonable to assume for that part of the restricted land that is publically owned, which for our case watershed is most of the restricted land.

A few directions for future work are suggested by this discussion. Where CLUE-S is a pattern-based land-use change model, alternative process-based systems, often agent-based systems, focus more explicitly on the agent making the land-use choice $[75,76]$. Moving in this direction is consistent with continuing calls to better integrate human behavior into coupled human-environmental systems analysis [77-80]. Where the current land-use change is based on transition probabilities informed by the observed pattern of land use, in an agent-based land-use change model, land use is chosen by a model agent, in response to changes in those things that impact the agent's objective. Incentive-based policies and market mediated influences can thereby be incorporated into the model and their consequences observed (as suggested in [81]). 
Our analysis does not explicitly evaluate 'best' patterns of land use. Doing so would require making judgements about the relative values of different functions provided by the landscape. It would be possible to assign a value reflecting the services provided by each cell in the simulation, based on the land use in that cell. These values could then be aggregated for each scenarios, and then the scenarios can be ranked [82-84]. The source of these values is the challenge with such an approach, as the choice of the values will determine which policy scenario is ranked highest. Engaging communities with the ranking or valuation of these landscape functions is receiving attention in this area and could be pursued as an application of these results $[62,63,85]$.

The identified challenge of governance fragmentation suggests that future work would be more valuable if it is undertaken more collaboratively with those that would use and be impacted by the results [86]. An agent-based approach lends itself to participatory model building in a way that pattern-based systems like CLUE-S do not [78,87]. Engaging local government, staff from provincial and federal ministries, and land users with the process of building the land-use change model builds an appreciation of the complex interactions that are at play, and fosters a sense of ownership of the model and therefore an acceptance of the results $[88,89]$. We expect the results of the current project can serve as a starting point for a conversation about the complexities involved in managing a multifunctional landscape and building both tools and relationships that can improve the quality of this management.

\section{Conclusions}

The Okanagan Valley has seen continuing rapid population growth for several decades, growth which is likely to continue. The challenge is finding that pattern of land use which best reflects the value that society places on the multiple functions provided by the landscape and then figuring out how to achieve this best pattern. We have herein reported on the use of a land-use change forecasting system to explore how land use is likely to change in the Deep Creek sub-basin of the Okanagan Valley under four different forest conservation policy scenarios. Our results demonstrate that failing to consider the multifunctional nature of the landscape when implementing policies can have unintended consequences. In this case, protecting forest land drives development onto agricultural land and may hasten the loss of low elevation forest. With provincial food sovereignty and enabling ecosystem adaptation to climate change of importance to the provincial population, the best form of the landscape will balance these functions with those provided by forest alone.

Bringing results like these into the decision-making process can be frustrated by the fragmentation of land-use governance. The pervasiveness of externalities requires considering the impacts of decisions beyond individual land owners and local communities. However, delegation of authority without processes to ensure coordination can lead to decisions that do not reflect the complexity of the system. Good land-use management therefore requires integrating knowledge and reflecting values from multiple affected communities. Recent innovations in land-use planning technologies and processes hold the promise to transform land-use planning into a process that builds collaboration and enables better coordination. Decision makers at all levels should actively pursue these new approaches to land-use planning.

Author Contributions: Conceptualization, M.A., J.J., C.N., and A.W.; methodology, M.A.; software, M.A.; validation, M.A.; formal analysis, M.A. and J.J.; writing—original draft preparation, M.A.; writing-review and editing, J.J. and C.N.; visualization, M.A. and J.J.; funding acquisition, A.W.

Funding: This research was funded by the Canadian Natural Science and Engineering Research Council and the University of British Columbia.

Acknowledgments: We are grateful to local government staff who reviewed and commented on our results.

Conflicts of Interest: The authors declare no conflicts of interest. The funders had no role in the design of the study; in the collection, analyses, or interpretation of data; in the writing of the manuscript; or in the decision to publish the results. 


\section{References}

1. Robinson, P.A. Field of Dreams; Universal Pictures: New York, NY, USA, 1989.

2. Statistics Canada. CANSIM Table 36-10-0402-01. Available online: www.statscan.gc.ca (accessed on 31 May 2019).

3. Stefanick, L. Baby stumpy and the war in the woods: Competing frames of British Columbia forests. $B C$ Stud. B. C. Q. 2001, 130, 41-68.

4. Cormier, J.; Tindall, D.B. Wood Frames: Framing the Forests in British Columbia. Sociol. Focus 2005, 38, 1-24. [CrossRef]

5. Hanna, K.S. Regulation and land-use conservation: A case study of the British Columbia Agricultural Land Reserve. J. Soil Water Conserv. 1992, 52, 166-170.

6. Tatebe, K.; Robert, N.; Liu, R.; delle Rosa, A.; Wirsching, E.; Mullinix, K.; Richard Bullock, F.; Bullock, R. Protection is Not Enough: Policy Precedents to Increase Agricultural Use of BC's Farmland; A White Paper; The Institute for Sustainable Food Systems, British Columbia, Kwantlen Polytechnic University: Vancouver, BC, Canada, 2018.

7. Androkovich, R.; Desjardins, I.; Tarzwell, G.; Tsigaris, P. Land Preservation in British Columbia: An Empirical Analysis of the Factors Underlying Public Support and Willingness to Pay. J. Agric. Appl. Econ. 2008, 40, 999-1013. [CrossRef]

8. BC Agricultural Land Commission. Available online: http://www.alc.gov.bc.ca (accessed on 31 May 2019).

9. BC Ministry of Agriculture. Available online: https://www2.gov.bc.ca/gov/content/governments/ organizational-structure/ministries-organizations/ministries/agriculture (accessed on 31 May 2019).

10. Forest, Land, N.R.O. and R.D. Available online: https://www2.gov.bc.ca/gov/content/governments/ organizational-structure/ministries-organizations/ministries/forests-lands-natural-resource-operationsand-rural-development (accessed on 31 May 2019).

11. Province of British Columbia. Local Government Act; Province of British Columbia: Victoria, BC, Canada, 2015.

12. Verburg, P.H.; Soepboer, W.; Veldkamp, A.; Limpiada, R.; Espaldon, V.; Mastura, S.S.A. Modeling the Spatial Dynamics of Regional Land Use: The CLUE-S Model. Environ. Manag. 2002, 30, 391-405. [CrossRef]

13. Verburg, P.H.; Overmars, K.P. Dynamic Simulation of Land-Use Change Trajectories with the Clue-S Model. In Modelling Land-Use Change; Springer Netherlands: Dordrecht, The Netherlands, 2007; pp. 321-337.

14. Ping, J.; Nichol, C.; Wei, A. Numerical Groundwater Modeling in the Deep Creek Watershed (Final); I.K. Barber School of Arts and Sciences, The University of British Columbia: Kelowna, BC, Canada, 2010.

15. Demarchi, D.A. The British Columbia Ecoregion Classification; Ecosystem Information Section, Ministry of Environment: Victoria, BC, Canada, 2011.

16. Statistics Canada. Census Profile 2011: Armstrong, British Columbia. Available online: http://www12. statcan.gc.ca/census-recensement/2011/dp-pd/prof/ (accessed on 15 February 2013).

17. Statistics Canada. Census Profile 2011: Township of Spallumcheen, British Columbia; Statistics Canada: Ottawa, ON, Canada, 2011.

18. BC Stats. British Columbia Population Projections 2010 to 2036; BC Stats: Victoria, BC, Canada, 2010.

19. Chipeniuk, R. Planning for Amenity Migration in Canada. Mt. Res. Dev. 2004, 24, 327-335. [CrossRef]

20. Senese, D. Amenity resources and rural change in the Okanagan Valley of British Columbia. In The Rural-Urban Fringe in Canada: Conflict \& Controversy; Beesley, K., Ed.; Rural Development Institute, Brandon University: Brandon, MB, Canada, 2010; ISBN 978-1-895397-82-6.

21. Verburg, P. The CLUE-S Model, Tutorial CLUE-S (version 2.4) and DYNA-CLUE (version 2); Institute for Environmental Studies, Free University Amsterdam: Amsterdam, The Netherlands, 2007.

22. Neumann, K.; Stehfest, E.; Verburg, P.H.; Siebert, S.; Müller, C.; Veldkamp, T. Exploring global irrigation patterns: A multilevel modelling approach. Agric. Syst. 2011, 104, 703-713. [CrossRef]

23. Hurkmans, R.T.W.L.; Terink, W.; Uijlenhoet, R.; Moors, E.J.; Troch, P.A.; Verburg, P.H. Effects of land use changes on streamflow generation in the Rhine basin. Water Resour. Res 2009, 45, 6405. [CrossRef]

24. Wassenaar, T.; Gerber, P.; Verburg, P.H.; Rosales, M.; Ibrahim, M.; Steinfeld, H. Projecting land use changes in the Neotropics: The geography of pasture expansion into forest. Glob. Environ. Chang. 2007, 17, 86-104. [CrossRef] 
25. Castella, J.-C.; Boissau, S.; Trung, T.N.; Quang, D.D. Agrarian transition and lowland-upland interactions in mountain areas in northern Vietnam: Application of a multi-agent simulation model. Agric. Syst. 2005, 86, 312-332. [CrossRef]

26. Kucsicsa, G.; Popovici, E.-A.; Bălteanu, D.; Grigorescu, I.; Dumitraşcu, M.; Mitrică, B. Future land use/cover changes in Romania: Regional simulations based on CLUE-S model and CORINE land cover database. Landsc. Ecol. Eng. 2019, 15, 75-90. [CrossRef]

27. Huang, D.; Huang, J.; Liu, T. Delimiting urban growth boundaries using the CLUE-S model with village administrative boundaries. Land Use Policy 2019, 82, 422-435. [CrossRef]

28. Mohammady, M.; Moradi, H.R.; Zeinivand, H.; Temme, A.J.A.M.; Yazdani, M.R.; Pourghasemi, H.R. Modeling and assessing the effects of land use changes on runoff generation with the CLUE-s and WetSpa models. Theor. Appl. Climatol. 2018, 133, 459-471. [CrossRef]

29. Hughes, J.D.; Liu, J. MIKE SHE: Software for Integrated Surface Water/Ground Water Modeling. Ground Water 2008, 46, 797-802. [CrossRef]

30. Neilsen, D.; Duke, G.; Taylor, B.; Byrne, J.; Kienzle, S.; Van der Gulik, T. Development and Verification of Daily Gridded Climate Surfaces in the Okanagan Basin of British Columbia. Can. Water Resour. J. 2010, 35, 131-154. [CrossRef]

31. Sustainable Agriculture Management Branch. Regional District of North Okanagan Agricultural Overview; Sustainable Agriculture Management Branch, British Columbia Ministry of Agriculture: Victoria, BC, Canada, 2008.

32. Sustainable Agriculture Management Branch. Columbia Shuswap Regional District Agricultural Overview; Sustainable Agriculture Management Branch, British Columbia Ministry of Agriculture: Victoria, BC, Canada, 2009.

33. Anputhas, M.; Janmaat, J.A.; Nichol, C.F.; Wei, X. Modelling spatial association in pattern based land use simulation models. J. Environ. Manag. 2016, 181, 465-476. [CrossRef] [PubMed]

34. Mertens, B.; Poccard-Chapuis, R.; Piketty, M.-G.; Lacques, A.-E.; Venturieri, A. Crossing spatial analyses and livestock economics to understand deforestation processes in the Brazilian Amazon: The case of Sao Felix do Xingu in South Para. Agric. Econ. 2002, 27, 269-294.

35. Aguiar, A.P.D.; Câmara, G.; Escada, M.I.S. Spatial statistical analysis of land-use determinants in the Brazilian Amazonia: Exploring intra-regional heterogeneity. Ecol. Modell. 2007, 209, 169-188. [CrossRef]

36. Van der Gulik, T.W.; Neilsen, D.; Fretwell, R. Agriculture Water Demand Model: Report for the Okanagan Basin; British Columbia Ministry of Agriculture: Victoria, BC, Canada, 2010.

37. Province of British Columbia. Okanagan-Agricultural Land Use Inventory. Available online: https://www2.gov.bc.ca/gov/content/industry/agriculture-seafood/agricultural-land-and-environment/ strengthening-farming/planning-for-agriculture/agricultural-land-use-inventories/okanagan (accessed on 1 January 2010).

38. Ng, V. GIS Technical ALUI Reference Manual; British Columbia Ministry of Agriculture: Victoria, BC, Canada, 2010.

39. BC Ministry of Agriculture. AgFocus Field Guide; BC Ministry of Agriculture: Victoria, BC, Canada, 2017.

40. BC Ministry of Agriculture. AgFocus: A Surveyor's Guide to Conducting a Land Use Inventory; BC Ministry of Agriculture: Victoria, BC, Canada, 2014.

41. Geographic Data BC GeoBC. Available online: http://geobc.gov.bc.ca (accessed on 1 February 2014).

42. Soil Lanscapes of Canada Working Group. Soil Landscapes of Canada Version 3.2; Soil Lanscapes of Canada Working Group, Canadian Soil Information Service, Government of Canada: Ottawa, ON, Canada, 2010.

43. Yellow Pages Canada Canada411. Available online: www.canada411.ca (accessed on 1 February 2014).

44. Amato, U.; Antoniadis, A.; Carfora, M.F.; Colandrea, P.; Cuomo, V.; Franzese, M.; Pignatti, S.; Serio, C. Statistical Classification for Assessing PRISMA Hyperspectral Potential for Agricultural Land Use. IEEE J. Sel. Top. Appl. Earth Obs. Remote Sens. 2013, 6, 615-625. [CrossRef]

45. Riveiro-Valiño, J.A.; Álvarez-López, C.J.; Marey-Pérez, M.F. The use of discriminant analysis to validate a methodology for classifying farms based on a combinatorial algorithm. Comput. Electron. Agric. 2009, 66, 113-120. [CrossRef]

46. Davidson, N.J.; Close, D.C.; Battaglia, M.; Churchill, K.; Ottenschlaeger, M.; Watson, T.; Bruce, J. Eucalypt health and agricultural land management within bushland remnants in the Midlands of Tasmania, Australia. Biol. Conserv. 2007, 139, 439-446. [CrossRef] 
47. NASA Landsat Science. Available online: https://landsat.gsfc.nasa.gov/ (accessed on 31 May 2019).

48. Pontius, R.G.; Huffaker, D.; Denman, K. Useful techniques of validation for spatially explicit land-change models. Ecol. Modell. 2004, 179, 445-461. [CrossRef]

49. Pontius, R.G. Statistical Methods to Partition Effects of Quantity and Location During Comparison of Categorical Maps at Multiple Resolutions. Photogramm. Eng. Remote Sens. 2002, 68, 1041-1049.

50. Pontius, R.G.; Castella, J.-C.; de Nijs, T.; Duan, Z.; Fotsing, E.; Goldstein, N.; Kok, K.; Koomen, E.; Lippitt, C.D.; McConnell, W.; et al. Lessons and Challenges in Land Change Modeling Derived from Synthesis of Cross-Case Comparisons. In Trends in Spatial Analysis and Modelling; Springer: Cham, Switzerland, 2018; pp. 143-164.

51. Regional District of Columbia Shuswap. Official Community Plan; Regional District of Columbia Shuswap: Shuswap, BC, Canada, 2011.

52. Climate Action Secretariat. Carbon Tax; British Columbia Ministry of Agriculture and Food: Victoria, BC, Canada, 2012.

53. Regional District of North Okanagan. Official Community Plan; Regional District of North Okanagan: Vernon, BC, Canada, 2012.

54. O'Farrell, P.J.; Anderson, P.M. Sustainable multifunctional landscapes: A review to implementation. Curr. Opin. Environ. Sustain. 2010, 2, 59-65. [CrossRef]

55. Hobbs, R.J.; Higgs, E.; Hall, C.M.; Bridgewater, P.; Chapin, F.S.; Ellis, E.C.; Ewel, J.J.; Hallett, L.M.; Harris, J.; Hulvey, K.B.; et al. Managing the whole landscape: Historical, hybrid, and novel ecosystems. Front. Ecol. Environ. 2014, 12, 557-564. [CrossRef]

56. Klein, J.A.; Wolf, S.A. Toward Multifunctional Landscapes: Cross-Sectional Analysis of Management Priorities in New York's Northern Forest. Rural Sociol. 2007, 72, 391-417. [CrossRef]

57. Li, X.; Parrott, L. An improved Genetic Algorithm for spatial optimization of multi-objective and multi-site land use allocation. Comput. Environ. Urban Syst. 2016, 59, 184-194. [CrossRef]

58. Prestele, R.; Arneth, A.; Bondeau, A.; de Noblet-Ducoudré, N.; Pugh, T.A.M.; Sitch, S.; Stehfest, E.; Verburg, P.H. Current challenges of implementing anthropogenic land-use and land-cover change in models contributing to climate change assessments. Earth Syst. Dyn. 2017, 8, 369-386. [CrossRef]

59. Robinson, D.T.; Di Vittorio, A.; Alexander, P.; Arneth, A.; Barton, C.M.; Brown, D.G.; Kettner, A.; Lemmen, C.; O'Neill, B.C.; Janssen, M.; et al. Modelling feedbacks between human and natural processes in the land system. Earth Syst. Dyn. 2018, 9, 895-914. [CrossRef]

60. Jin, G.; Chen, K.; Wang, P.; Guo, B.; Dong, Y.; Yang, J. Trade-offs in land-use competition and sustainable land development in the North China Plain. Technol. Forecast. Soc. Chang. 2019, 141, 36-46. [CrossRef]

61. Lotze-Campen, H.; Verburg, P.H.; Popp, A.; Lindner, M.; Verkerk, P.J.; Moiseyev, A.; Schrammeijer, E.; Helming, J.; Tabeau, A.; Schulp, C.J.E.; et al. A cross-scale impact assessment of European nature protection policies under contrasting future socio-economic pathways. Reg. Environ. Chang. 2018, 18, 751-762. [CrossRef]

62. Adams, V.M.; Pressey, R.L.; Stoeckl, N. Navigating trade-offs in land-use planning: Integrating human well-being into objective setting. Ecol. Soc. 2014, 19, art53. [CrossRef]

63. Adams, V.M.; Pressey, R.L.; Álvarez-Romero, J.G. Using Optimal Land-Use Scenarios to Assess Trade-Offs between Conservation, Development, and Social Values. PLoS ONE 2016, 11, e0158350. [CrossRef]

64. Bakker, K.; Cook, C. Water Governance in Canada: Innovation and Fragmentation. Int. J. Water Resour. Dev. 2011, 27, 275-289. [CrossRef]

65. Zelli, F.; van Asselt, H. Introduction: The Institutional Fragmentation of Global Environmental Governance: Causes, Consequences, and Responses. Glob. Environ. Polit. 2013, 13, 1-13. [CrossRef]

66. BC Agriculture and Food Climate Action Initiative. Available online: https://www.bcagclimateaction.ca/ (accessed on 31 May 2019).

67. Latimer, S.; Peatt, S. Designing and Implementing Ecosystem Connectivity in the Okanagan; Okanagan Collaborative Conservation Program: Kelowna, BC, Canada, 2014.

68. Cannings, R.J. The South Okanagan Valley: A national treasure at risk. In Proceedings of the Conference on the Biology and Management of Species and Habitats at Risk, Kamloops, BC, Canada, 15-19 February 2000.

69. Tian, Q.; Holland, J.H.; Brown, D.G. Social and economic impacts of subsidy policies on rural development in the Poyang Lake Region, China: Insights from an agent-based model. Agric. Syst. 2016, 148, 12-27. [CrossRef] 
70. Zhang, Q.; Song, C.; Chen, X. Effects of China's payment for ecosystem services programs on cropland abandonment: A case study in Tiantangzhai Township, Anhui, China. Land Use Policy 2018, 73, $239-248$. [CrossRef]

71. Kinzig, A.P.; Perrings, C.; Chapin, F.S.; Polasky, S.; Smith, V.K.; Tilman, D.; Turner, B.L.; Coe, M.T.; Daily, G.C.; Gibbs, H.K.; et al. Paying for Ecosystem Services-Promise and Peril. Science 2011, 334, 603-604. [CrossRef] [PubMed]

72. Bryan, B.A. Incentives, land use, and ecosystem services: Synthesizing complex linkages. Environ. Sci. Policy 2013, 27, 124-134. [CrossRef]

73. Wang, Y.; Bilsborrow, R.E.; Zhang, Q.; Li, J.; Song, C. Effects of payment for ecosystem services and agricultural subsidy programs on rural household land use decisions in China: Synergy or trade-off? Land Use Policy 2019, 81, 785-801. [CrossRef]

74. Bateman, I.J.; Harwood, A.R.; Mace, G.M.; Watson, R.T.; Abson, D.J.; Andrews, B.; Binner, A.; Crowe, A.; Day, B.H.; Dugdale, S.; et al. Bringing ecosystem services into economic decision-making: Land use in the United Kingdom. Science 2013, 341, 45-50. [CrossRef] [PubMed]

75. Agent-Based Models of Land-Use and Land-Cover Change; Parker, D.C.; Berger, T.; Manson, S.M.; McConnell, W.J. (Eds.) LUCC International Project Office: Irvine, CA, USA, 2001.

76. Matthews, R.B.; Gilbert, N.G.; Roach, A.; Polhill, J.G.; Gotts, N.M. Agent-based land-use models: A review of applications. Landsc. Ecol. 2007, 22, 1447-1459. [CrossRef]

77. Irwin, E.; Campbell, J.; Wilson, R.; Faggian, A.; Moore, R.; Irwin, N. Human adaptations in food, energy, and water systems. J. Environ. Stud. Sci. 2016, 6, 127-139. [CrossRef]

78. Alberti, M.; Asbjornsen, H.; Baker, L.A.; Brozovic, N.; Drinkwater, L.E.; Drzyzga, S.A.; Jantz, C.A.; Fragoso, J.; Holland, D.S.; Kohler, T.A.; et al. Research on Coupled Human and Natural Systems (CHANS): Approach, Challenges, and Strategies. Bull. Ecol. Soc. Am. 2011, 92, 218-228. [CrossRef]

79. Ren, Y.; Lü, Y.; Comber, A.; Fu, B.; Harris, P.; Wu, L. Spatially explicit simulation of land use/land cover changes: Current coverage and future prospects. Earth-Sci. Rev. 2019, 190, 398-415. [CrossRef]

80. Walsh, S.J.; Mena, C.F. Interactions of social, terrestrial, and marine sub-systems in the Galapagos Islands, Ecuador. Source 2016, 113, 14536-14543. [CrossRef] [PubMed]

81. Verburg, P.H.; Alexander, P.; Evans, T.; Magliocca, N.R.; Malek, Z.; Rounsevell, M.D.A.; van Vliet, J. Beyond land cover change: Towards a new generation of land use models. Curr. Opin. Environ. Sustain. 2019, 38, 77-85. [CrossRef]

82. Tammi, I.; Mustajärvi, K.; Rasinmäki, J. Integrating spatial valuation of ecosystem services into regional planning and development. Ecosyst. Serv. 2017, 26, 329-344. [CrossRef]

83. Hein, L.; van Koppen, K.; de Groot, R.S.; van Ierland, E.C. Spatial scales, stakeholders and the valuation of ecosystem services. Ecol. Econ. 2006, 57, 209-228. [CrossRef]

84. Zhao, M.; He, Z.; Zhao, M.; He, Z. Evaluation of the Effects of Land Cover Change on Ecosystem Service Values in the Upper Reaches of the Heihe River Basin, Northwestern China. Sustainability 2018, 10, 4700. [CrossRef]

85. Henríquez-Dole, L.; Usón, T.J.; Vicuña, S.; Henríquez, C.; Gironás, J.; Meza, F. Integrating strategic land use planning in the construction of future land use scenarios and its performance: The Maipo River Basin, Chile. Land Use Policy 2018, 78, 353-366. [CrossRef]

86. Ariti, A.T.; van Vliet, J.; Verburg, P.H. Farmers' participation in the development of land use policies for the Central Rift Valley of Ethiopia. Land Use Policy 2018, 71, 129-137. [CrossRef]

87. Van Berkel, D.B.; Verburg, P.H. Combining exploratory scenarios and participatory backcasting: Using an agent-based model in participatory policy design for a multi-functional landscape. Landsc. Ecol. 2012, 27, 641-658. [CrossRef] [PubMed] 
88. Schaller, L.; Targetti, S.; Villanueva, A.J.; Zasada, I.; Kantelhardt, J.; Arriaza, M.; Bal, T.; Fedrigotti, V.B.; Giray, F.H.; Häfner, K.; et al. Agricultural landscapes, ecosystem services and regional competitiveness-Assessing drivers and mechanisms in nine European case study areas. Land Use Policy 2018, 76, 735-745. [CrossRef]

89. Zasada, I.; Häfner, K.; Schaller, L.; van Zanten, B.T.; Lefebvre, M.; Malak-Rawlikowska, A.; Nikolov, D.; Rodríguez-Entrena, M.; Manrique, R.; Ungaro, F.; et al. A conceptual model to integrate the regional context in landscape policy, management and contribution to rural development: Literature review and European case study evidence. Geoforum 2017, 82, 1-12. [CrossRef]

(C) 2019 by the authors. Licensee MDPI, Basel, Switzerland. This article is an open access article distributed under the terms and conditions of the Creative Commons Attribution (CC BY) license (http://creativecommons.org/licenses/by/4.0/). 